\title{
Uji Sitotoksik Ekstrak Daun Murbei (Morul Alba L) Terhadap Sel Kanker Mcf-7 Dan Selektifitasnya
}

\author{
Lukman $^{\left.1^{*}\right)}$, Marwati' ${ }^{2)}$, Suwahyuni Mus ${ }^{3)}$, Reny Syahruni' ${ }^{2)}$ \\ 1) Bagian Kimia Farmasi, Sekolah Tinggi Ilmu Farmasi Makassar, Jl. Perintis Kemerdekaan KM 13,7, \\ Makassar, Sulawesi Selatan \\ 2) Bagian Biologi Farmasi, Sekolah Tinggi Ilmu Farmasi Makassar, Jl. Perintis Kemerdekaan KM 13,7, \\ Makassar, Sulawesi Selatan \\ 3) Bagian Farmakologi, Sekolah Tinggi Ilmu Farmasi Makassar, Jl. Perintis Kemerdekaan KM 13,7, Makassar, \\ Sulawesi Selatan \\ Email : Lukman_m01@yahoo.co.id
}

\begin{abstract}
Mulberry, Morus alba L., is traditionally used to treat various diseases such as bacterial, fungal, and protozoal. In addition, the society in South Sulawesi uses mulberry leaves as an anti-cancer. The present study aimed to investigate the cytotoxic effect of mulberry leaf extract on breast cancer cells $M C F-7$ and their selectivity against Vero normal cells. The dried mulberry leaves were extracted by maceration using $96 \%$ ethanol. The cytotoxic activity was determined using MTT method, while the selectivity index (SI) was calculated by comparing IC 50 of MCF-7 cells against Vero cells. The results showed that the ethanol extract of mulberry leaves was toxic to MCF-7 cells with an IC $\mathrm{C}_{50}$ of $75.32 \pm 2.78 \mu \mathrm{g} / \mathrm{mL}$ and also toxic to Vero cells $(71.73 \pm 4.39 \mu \mathrm{g} / \mathrm{mL})$. However, ethanol extract of mulberry leaves was not selective on MCF-7 cells with an SI value of 0.95. Our study indicates that mulberry could be considered an effective agent in the prevention of cancer, but further studies are necessary needed for safety assessment.
\end{abstract}

Keywords: Cytotoxic, Morus alba L., MTT, Selectivity

\begin{abstract}
ABSTRAK
Murbei (Morus alba L.) secara tradisional dipergunakan untuk mengobati berbagai macam penyakit seperti infeksi bakteri, jamur dan protozoa. Selain itu masyarakat Sulawesi Selatan memanfaatkan daun murbei sebagai obat anti kanker. Penelitian ini bertujuan untuk membuktikan efek sitotoksik daun murbei terhadap sel kanker payudara MCF-7 dan selektivitasnya terhadap sel normal Vero. Daun murbei yang telah dikeringkan diekstraksi secara maserasi menggunakan etanol 96\%. Uji sitotoksik ditentukan menggunakan metode MTT sedangkan indeks selektivitas (IS) dihitung dengan membandingkan $\mathrm{IC}_{50}$ sel MCF-7 terhadap sel Vero. Hasil penelitian menunjukkan bahwa ekstrak etanol daun murbei bersifat toksik terhadap sel MCF-7 dengan $\mathrm{IC}_{50} 75,32 \pm 2,78 \mu \mathrm{g} / \mathrm{mL}$, akan tetapi juga bersifat toksik terhadap sel Vero dengan $\mathrm{IC}_{50} 71,73 \pm 4,39 \mu \mathrm{g} / \mathrm{mL}$. Ekstrak etanol daun murbei tidak selektif terhadap sel MCF-7 dengan nilai IS sebesar 0,95. Data tersebut menunjukkan bahwa ekstrak etanol daun murbei berpotensi dikembangkan sebagai kandidat obat kanker meskipun perlu penelitian lebih lanjut mengenai keamanannya.
\end{abstract}

Kata kunci: Morus alba L., Sitotoksik, Selektivitas, MTT

\section{PENDAHULUAN}

Kanker merupakan suatu istilah kedokteran yang mengarah kepada tumor, maligna, neoplasma atau blastoma yang ditandai dengan adanya perkembangan atau proliferasi sel yang tidak normal. Penyakit ini dapat menyerang semua ras dan ditemukan di seluruh dunia
(Esfahani et al., 2020; Siegel et al., 2021). Menurut hasil Riset Kesehatan Dasar (RISKESDAS) 2018, penderita kanker di Indonesia meningkat setiap tahunnya. Ada banyak jenis kanker pada manusia akan tetapi kanker payudara merupakan jenis kanker yang paling banyak ditemui pada wanita. Insiden 
kanker payudara di Indonesia adalah sebesar 26 per 100.000 penduduk (KEMENKES RI, 2018).

Sekarang ini telah banyak diperkenalkan strategi untuk mengobati kanker seperti kemoterapi, radiasi dan pembedahan. Kemoterapi dinilai lebih efektif untuk membunuh sel kanker terutama pada pasien yang tidak memungkinkan untuk menjalani pembedahan akan tetapi mempunyai banyak efek samping. Efek samping umum yang ditemui seperti kebotakan, rasa terbakar, penurunan sistem imun, rentang terinfeksi dan mual, sehingga diperlukan alternatif kemoterapi yang tidak atau rendah efek samping akan tetapi sama efektifnya (Kuruppu et al., 2019; Schirrmacher, 2019). Salah satu strategi yang dapat dilakukan adalah dengan pemanfaatan bahan alam (Abu-Darwish \& Efferth, 2018).

Bahan alam seperti murbei (Morus alba L.) secara tradisional di Provinsi Sulawesi Selatan digunakan pada pengobatan kanker. Selain itu, tanaman ini juga dipergunakan pada pengobatan infeksi bakteri, jamur dan protozoa (Manggau \& Lukman, 2012). Menurut Fallah et al. (2017) flavonoid yang terkandung dalam daun murbei bersifat toksik terhadap sel kanker mulut rahim (HeLa). Flavonoid tersebut membunuh sel HeLa dengan cara menginduksi jalur apoptosis memalui aktivasi sitotokrom pada sitosol mitokondria (Fallah et al., 2017). Akar murbei dilaporkan mampu membunuh sel kanker leukimia K562 and B380 serta sel melanoma mencit B16 melalui mekanisme apoptosis (Nam et al., 2002). Apoptosis merupakan jalur kematian sel yang tidak melalui proses inflamasi (Carneiro \& El-Deiry, 2020).

Untuk menguji efek anti kanker suatu tanaman dapat dilakukan melalui uji sitotoksik menggunakan model sel kanker. Ada banyak model sel yang dapat digunakan seperti HeLa, RAJ, K562, NB4, MCF-7, Vero dan sebagainya (Comsa et al., 2015; Mirabelli et al., 2019). Penelitian ini menggunakan sel kanker MCF-7 sebagai model sel kanker payudara dan sel Vero sebagai sel normal. Adapun tujuan dari penelitian ini adalah mengetahui efek sitotoksik daun murbei terhadap sel kanker payudara MCF-7 dan selektivitasnya terhadap sel normal Vero.

\section{METODE PENELITIAN Pengambilan sampel}

Sampel daun murbei diperoleh dari Kabupaten Soppeng, Sulawesi Selatan yang dipanen pada bulan Februari 2018. Daun yang telah dipetik selanjutnya dicuci dengan air mengalir dan dikeringkan menggunakan oven simplisia pada suhu $40^{\circ} \mathrm{C}$ selama 36 jam dan dilakukan pengecilan ukuran sampel.

\section{Pembuatan ekstrak}

Daun yang telah dikeringkan dimaserasi dengan etanol 96\% selama 3x24 jam sambil sesekali diaduk dan terlindung dari sinar matahari langsung. Re-maserasi dilakukan sebanyak 3 kali, semua filtrat dikumpulkan dan diuapkan menggunakan rotary evaporator (Buchi) hingga didapatkan ekstrak kental. Ekstrak kental selanjutnya dimasukkan ke dalam desikator.

Kultur sel

Penelitian ini menggunakan 2 jenis sel uji yaitu sel MCF-7 dan Vero. Baik sel MCF-7 maupun sel Vero kedua-duanya ditumbuhkan menggunakan medium Dulbecco's Modified Eagle Medium (DMEM) yang mengandung 5\% Fetal Bovine Serum (FBS); 1\% penisilinstreptomisin; dan $0,5 \%$ amfoterisin A kemudian diinkubasi pada suhu $37^{\circ} \mathrm{C}$ dalam inkubator $\mathrm{CO}_{2}$ $5 \%$. Panen sel dilakukan dengan penambahan tripsin-EDTA setelah sel konfluens.

\section{Uji sitotoksik}

Uji sitotoksik ekstrak etanol daun murbei dilakukan dengan metode MTT sebagaimana yang diuraian oleh Pakki et al. (2019) dan Tanumihardja et al. (2020) dengan sedikit modifikasi (Pakki et al., 2019; Tanumihardja et al., 2020). Sebanyak $100 \mu \mathrm{L}$ suspensi sel $\left(10^{4}\right.$ $\mathrm{sel} / \mathrm{mL}$ ) dimasukkan ke dalam wellplate 96 dan diinkubasi selama 24 jam kemudian ditambahkan $100 \mu \mathrm{L}$ ekstrak dengan berbagai variasi konsentrasi $(7,81-500,00 \mu \mathrm{g} / \mathrm{mL})$. Larutan 3(4,5-dimethylthiazol-2-yl)-2,5-

diphenyltetrazolium bromide (MTT) konsentrasi $0,5 \mathrm{mg} / \mathrm{mL}$ ditambahkan kedalam masing-masing sumuran dan dinkubasi kembali selama 4 jam. Reaksi dihentikan dengan penambahan sodium dodecyl sulfate (SDS) 10\%. Absorbansi masingmasing sumuran diukur menggunakan microplate 
reader (Thermo) pada lambda $595 \mathrm{~nm}$. Persen penghambatan dihitung dengan rumus:

Penghambatan $(\%)=\frac{\text { OD kontrol sel }- \text { OD sampel }}{\text { OD kontrol sel }} \times 100$

Sedangkan $\mathrm{IC}_{50}$ dihitungkan menggunakan perangkat lunak GraphPad 8.0.

\section{Indeks selektivitas (SI)}

SI dihitungkan dengan menggunakan rumus: $\mathrm{SI}=\frac{\mathrm{IC}_{50} \text { sel Vero }}{\mathrm{IC}_{50} \text { sel MCF-7 }}$

\section{HASIL DAN PEMBAHASAN \\ Rendemen ekstrak}

Ekstrak didefinisikan sebagai zat atau material yang dihasilkan melalui ekstraksi bahan mentah secara kimiawi sedangkan ekstraksi adalah proses untuk mendapatkan atau menghasilkan ekstrak. Efisiensi suatu proses ekstraksi dapat dilihat dari nilai rendemen (Pakki et al., 2020). Semakin tinggi nilai rendemen mengindikasi semakin banyak ekstrak yang dihasilkan meskipun hingga saat ini belum ada standar nilai rendemen yang disepakati. Nilai rendemen ekstrak etanol daun murbei dalam penelitian ini adalah 13,26 $\pm 3,26 \%$.

\section{Efek sitotoksik}

Kemampuan suatu zat untuk membunuh sel kanker dapat diukur melalui uji sitotoksik menggunakan metode MTT. Prinsip dari metode ini adalah adanya perubahan warna kuning dari tetrazolium MTT menjadi formazan yang berwarna ungu. MTT hanya akan diabsorpsi oleh sel hidup dan direduksi oleh enzim reduktase dalam mitokondria menjadi garam formazan yang tidak larut dalam air. Untuk melarutkan garam formazan dan menghentikan reaksi maka ditambahkan SDS 10\%. Semakin berwarna ungu artinya semakin banyak pula sel yang hidup, begitu pula sebaliknya (Benov, 2019; Rai et al., 2018). Adapun hasil uji sitotoksik ekstrak etanol daun murbei terhadap sel MCF-7 dan Vero dapat dilihat pada Gambar 1 .

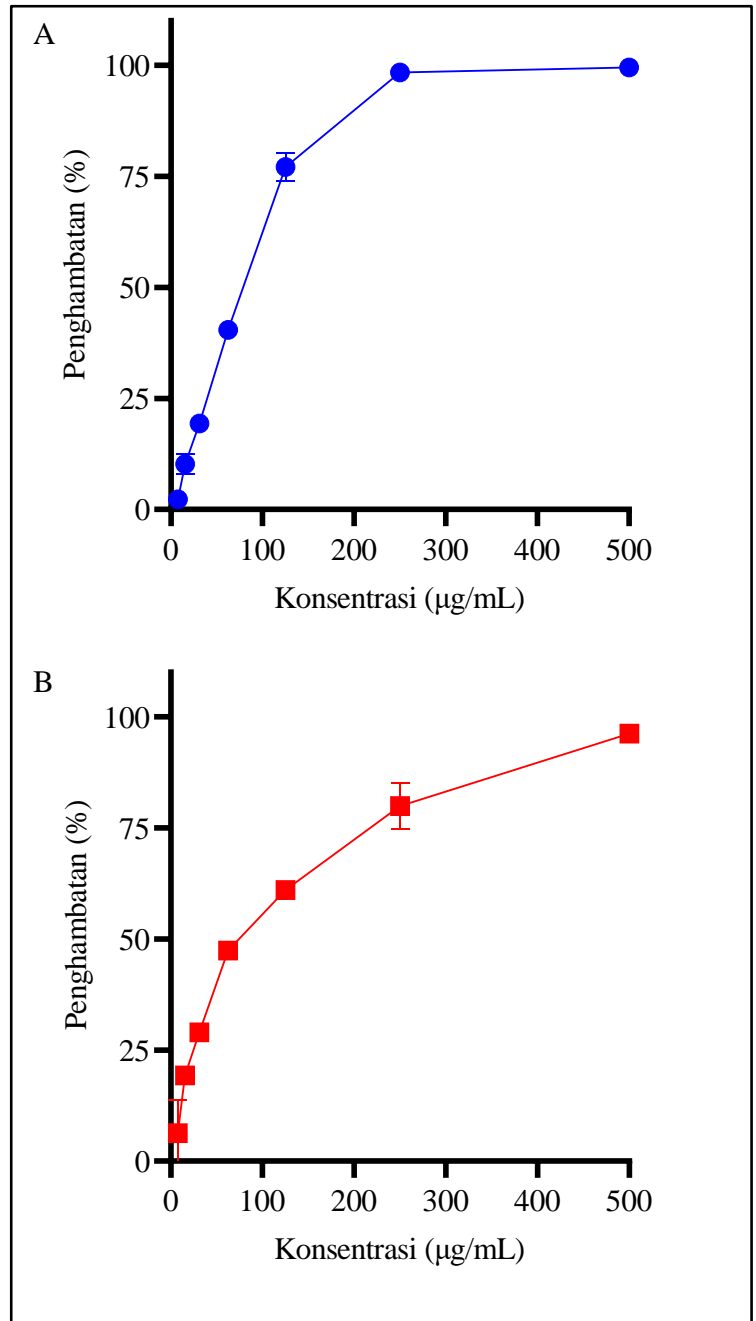

Gambar 1 Efek sitotoksik ekstrak etanol daun murbei setelah kontak selama 24 jam terhadap: (A) sel MCF-7; dan (B) sel Vero. Data berasal dari 3 kali pengulangan dan disajikan dalam bentuk rata-rata \pm standar deviasi (SD)

Semakin tinggi konsentrasi ekstrak etanol daun murbei yang digunakan maka semakin besar pula efek sitotoksiknya atau dikenal sebagai dosedependent manner. Efek sitotoksik mulai terlihat pada konsentrasi $15,63 \mu \mathrm{g} / \mathrm{mL}$ sebesar $10,19 \pm 2,33 \%$ terhadap sel MCF-7 dan mencapai kematian maksimum pada konsentrasi 250,00 $\mu \mathrm{g} / \mathrm{mL}$ sebesar $98,37 \pm 0,62 \%$ (Gambar 1A). Hal ini menunjukkan bahwa ekstrak etanol daun murbei mempunyai efek sitotoksik terhadap sel kanker.

Kandidat sel kanker yang baik harus toksik terhadap sel kanker akan tetapi aman (tidak toksik) terhadap sel normal (Andreani et al., 2017). Untuk menyelidiki hal tersebut maka 
penelitian ini juga menguji ekstrak etanol daun murbei terhadap sel normal yaitu Vero. Hasil penelitian menunjukkan bahwa ekstrak juga bersifat sitotoksik terhadap sel Vero. Berdasarkan Gambar 1B terlihat bahwa efek sitotoksik mulai terlihat pada konsentrasi $15,63 \mu \mathrm{g} / \mathrm{mL}$ sebesar $19,30 \pm 1,37 \%$ dan mencapai kematian maksimum pada konsentrasi $500,00 \mu \mathrm{g} / \mathrm{mL} \quad$ sebesar $96,17 \pm 1,81 \%$.

Efek sitotoksik suatu zat dinilai dari besaran nilai half maximal inhibitory concentration atau yang lebih dikenal $\mathrm{IC}_{50}$. $\mathrm{IC}_{50}$ adalah konsentrasi yang dapat membunuh 50\% sel kanker. Semakin kecil nilai IC $_{50}$ maka semakin besar pula aktivitas sitotoksiknya. Nilai $\mathrm{IC}_{50}$ ekstrak etanol daun murbei terhadap sel MFC-7 adalah 75,32 $\pm 2,78 \mu \mathrm{g} / \mathrm{mL}$ dan terhadap sel Vero adalah 71,73 $\pm 4,39 \mu \mathrm{g} / \mathrm{mL}$. Menurut Nordin et al. (2018) aktivitas sitotoksik suatu zat dapat dikategorikan berdasarkan pada nilai $\mathrm{IC}_{50}$. Nilai $\mathrm{IC}_{50} \leq 20 \mu \mathrm{g} / \mathrm{mL}$ kategori sangat aktif, 20$100 \mu \mu \mathrm{g} / \mathrm{mL}$ kategori aktif, 100-1000 kategori sangat lemah, dan $\geq 1000$ kategori tidak aktif (Nordin et al., 2018). Berdasarkan hal tersebut maka ekstrak etanol daun murbei bersifat aktif terhadap sel kanker.

\section{Indeks selektivitas}

Untuk mengetahui selektivitas suatu zat sebagai anti kanker dapat diliat dari nilai IS-nya. Suatu zat dikatakan selektif jika memiliki nilai IS $>2$ (Wardihan et al., 2013). Pada penelitian ini didapatkan nilai IS sebesar 0,95. Hal ini menunjukkan bahwa ekstrak etanol daun murbei tidak selektif terhadap sel kanker.

\section{KESIMPULAN}

Penelitian ini membuktikan bahwa penggunaan daun murbei dimasyarakat yang seraca empiris pada pengobatan kanker terbukti secara ilmiah. Hasil penelitian ini menunjukkan bahwa ekstrak etanol daun murbei bersifat aktif terhadap sel MCF-7 dengan $\mathrm{IC}_{50} 75,32 \pm 2,78 \mu \mathrm{g} / \mathrm{mL}$ akan tetapi tidak selektif karena juga aktif terhadap sel normal Vero dengan $\mathrm{IC}_{50} 71,73 \pm 4,39 \mu \mathrm{g} / \mathrm{mL}$. Oleh karena itu, daun murbei berpotensi untuk dikembangkan sebagai kandidat obat kanker meskipun perlu penelitian lebih lanjut mengenai keamanannya.

\section{DAFTAR PUSTAKA}

Abu-Darwish MS, Efferth T. 2018. Medicinal plants from near east for cancer therapy. Front Pharmacol 9; e56

Andreani NA, Renzi S, Piovani G, Ajmone Marsan P, Bomba L, Villa R, Ferrari M, Dotti S. 2017. Potential neoplastic evolution of Vero cells: In vivo and in vitro characterization. Cytotechnology 69(5); $741-50$

Benov L. 2019. Effect of growth media on the MTT colorimetric assay in bacteria. PLoS One 14(8); e0219713

Carneiro BA, El-Deiry WS. 2020. Targeting apoptosis in cancer therapy. Nat Rev Clin Oncol 17(7); 395-417

Comsa S, Cîmpean AM, Raica M. 2015. The Story of MCF-7 breast cancer cell line: 40 years of experience in research. Anticancer Res 35(6); 3147-54

Esfahani K, Roudaia L, Buhlaiga N, Del Rincon SV, Papneja N, Miller WH, Jr. 2020. A review of cancer immunotherapy: From the past, to the present, to the future. Curr Oncol 27(Suppl 2); S87-S97

Fallah S, Hajihassan Z, Sadeghi A. 2017. Cytotoxicity effects of flavonoid extract of Morus alba leaves in Hela cell line. Asian J Biol Sci 10; 72-79

KEMENKES RI. 2018. Hasil utama RISKEDAS 2018. Badan Penelitian dan Pengembangan Kesehatan, Kementerian Kesehatan RI. Jakarta

Kuruppu AI, Paranagama P, Goonasekara CL. 2019. Medicinal plants commonly used against cancer in traditional medicine formulae in Sri Lanka. Saudi Pharm J 27(4); $565-73$

Manggau MA, Lukman M. 2012. Efek farmakologi tanaman antikanker yang digunakan oleh masyarakat suku Makassar Sulawesi Selatan. LepHas. Makassar

Mirabelli P, Coppola L, Salvatore M. 2019. Cancer cell lines are useful model systems for medical research. Cancers 11(8); e1098 
Nam SY, Yi HK, Lee JC, Kim JC, Song CH, Park JW, Lee DY, Kim JS, Hwang PH. 2002. Cortex mori extract induces cancer cell apoptosis through inhibition of microtubule assembly. Arch Pharm Res 25(2); 191-96

Nordin ML, Abdul Kadir A, Zakaria ZA, Abdullah R, Abdullah MNH. 2018. In vitro investigation of cytotoxic and antioxidative activities of Ardisia crispa against breast cancer cell lines, MCF-7 and MDA-MB231. BMC Complement Altern Med 18(1); e87

Pakki E, Alam G, Usmar, Syukur R, Muslimin L. 2019. Anticancer activity of selected medicinal plants indigenous to Duri ethnic. Int J Pharm Sci Res 11(Supplementary 1); 602-08

Pakki E, Tayeb R, Usmar U, Ridwan IA, Muslimin L. 2020. Effect of orally administered combination of Caulerpa racemosa and Eleutherine americana (Aubl) Merr extracts on phagocytic activity of macrophage. Res Pharm Sci 15(4); 40109

Rai Y, Pathak R, Kumari N, Sah DK, Pandey S, Kalra N, Soni R, Dwarakanath BS, Bhatt
AN. 2018. Mitochondrial biogenesis and metabolic hyperactivation limits the application of MTT assay in the estimation of radiation induced growth inhibition. Scientific Reports 8(1); e1531

Schirrmacher V. 2019. From chemotherapy to biological therapy: A review of novel concepts to reduce the side effects of systemic cancer treatment (Review). Int J Oncol 54(2); 407-19

Siegel RL, Miller KD, Fuchs HE, Jemal A. 2021. Cancer Statistics, 2021. CA Cancer J Clin 71(1); 7-33

Tanumihardja M, Hastuti S, Nugroho JJ, Trilaksana AC, Natsir N, Rovani CA, Muslimin L. 2020. Viabilities of odontoblast cells following addition of haruan fish in calcium hydroxide. Open Access Maced J Med Sci 8(D); 58-63

Wardihan, Rusdi M, Alam G, Muslimin L, Manggau MA. 2013. Selective cytotoxicity evaluation in anticancer drug screening of Boehmeria virgata (Forst) Guill leaves to several human cell lines: HeLa, WiDr, T47D and Vero. Dhaka Univ J Pharm Sci 12(2); 123-26 